\title{
Competing priorities: Student perceptions of helps and hindrances to language acquisition during study abroad
}

\author{
Marcie J. Pyper \\ Calvin College \\ Cynthia Slagter \\ Calvin College
}

Krashen's (1981) commonly accepted hypothesis that extensive comprehensible input is necessary for language acquisition has led language educators to promote language immersion through study abroad (SA) as a key context for learning language. However, researchers have discovered a gap between an idealized vision of the SA context and the realities of student engagement during their off campus experiences. While the efficacy of SA for language development has been widely researched (Brecht, et al., 1995; Freed, 1995; Hernández, 2010; Lafford \& Collentine, 2006; Magnan \& Back, 2007; Mendelson, 2004; Segalowitz \& Freed, 2004), university language departments and study abroad programs tend to overestimate the amount of progress a student can make in language skills during study abroad. At the same time, both students and professors tend to underestimate the barriers to language gain, which include a wide range of complex variables such as student motivation (Dörnyei, 1990; Hernández, 2010), living arrangements (Di Silvio, et al., 2014), meaningful interaction with target language (TL) speakers (Allen, 2010), and educational culture (Brecht, et al., 1995). Wilkinson (1998) has noted "that increased nonclassroom interaction in the target language and miraculous linguistic gains are not inevitable in the study-abroad setting" (33). The common belief that substantial gains in TL proficiency are an automatic outcome of time spent in study abroad can no longer be assumed to be true. However, while researchers may recognize these limitations, students still expect to attain extraordinary levels of language growth simply by being immersed in the host country.

In reality, total linguistic immersion is, in most cases, an illusion. Contemporary students may physically be in a second language (L2) setting, but their hearts and minds are often drawn home through the wonders of modern technology such as email, Facebook, Skype, and other social media. Even students who deny themselves the use of social media while abroad face an uphill battle when trying to remain faithful to their linguistic commitments. Kinginger (2010) recognizes an additional hurdle that students face today, in "the domination of English as the acknowledged lingua mundi" (224). She warns,

American students abroad increasingly encounter their own language in the settings they frequent. English is the preferred medium for exchanges among their fellow international students, and competence and interaction in English are in demand....These students, more and more, need to choose to foreground their identity as language learners if they are to learn languages. (224)

In addition to the challenges of technology and English omnipresence, language learning during SA is complicated by student perceptions of the language-learning context, peer interaction, home stay, academic setting, and their reactions to these perceptions. Allen (2010) notes that "[SA] participants...held divergent perceptions of how others in the learning environment contributed to 
their language learning, and those perceptions, in turn, mediated their choices and behaviors related to interactions" (19). Helping students become aware of their attitudes and perceptions is a first step toward helping them modify behaviors to enable them to improve their L2 acquisition.

\section{L2 Contact and Language Proficiency Gain}

Researchers of L2 acquisition during study abroad have examined the L2 context (at home, intensive domestic immersion, and study abroad) along with L2 contact (how much and with whom). Some L2 contact studies distinguish between contact with native speaking host families and local community members. Other L2 contact studies examine students' linguistic interaction with native speakers in the host country in contrast to engagement with their non-native L2 peers.

Multiple studies have investigated the effect of language contact on language proficiency, testing the assumption that the SA context means greater L2 contact, with varying results. Segalowitz and Freed (2004) compared at home (AH) and study abroad language learning and found that SA learners showed significant progress in oral proficiency while AH did not. However, their findings problematize the assumed connection between SA and language gain when they note that "the gains made in the SA context did not simply reflect greater out-of-class contact or prior study time. Thus... although the AH and SA learning contexts did differentially support gains in oral performance, this difference is probably not related in any direct or simple way to in-class or out-of-class time-ontask factors" (192).

Interestingly, when Freed, Segalowitz and Dewey (2004) compared traditional AH language study with intensive domestic immersion (IM) and SA immersion they found that the students in the IM group made the most progress in fluency. The authors suggest that this difference might be explained by the fact that the IM students reported "significantly more contact hours in French than the other two groups" (291). This result highlights the fact that the SA context does not always guarantee increased L2 contact or L2 gain; however, it does support the assumption that increased contact correlates with increased gain.

In his study, Hernández (2010) also attributes gains in language learning to contact with L2, concluding that "student contact with the Spanish language has a significant effect on their speaking improvement" (610). He recognizes that while his findings confirm the results of some researchers (Brecht et al., 1995; Isabelli-Garcia, 2006; Magnan \& Back, 2007) they contradict the conclusions of Segalowitz and Freed (2004). He attributes this difference to the amount of L2 contact time reported by the students in each study, saying "the study-abroad participants in Segalowitz and Freed's study reported participating in out-of-class language activities for an average of 18 hours per week. In contrast, the study-abroad students in the present investigation reported participating in similar outof-class activities for an average of 60.68 hours per week" (608). This startling difference may not be as large as it initially appears. Indeed, a closer examination suggests that the 18 hours reported by Segalowitz and Freed only represents the time spent speaking to native speakers whereas Hernández's 60.68 hours include 16.8 hours spent speaking Spanish and nearly 44 hours spent in activities such as reading and writing homework, listening to music, or watching TV in Spanish. Thus, the comparison is imperfect and the Hernández findings appear inconclusive at best.

Studies examining the effects of home stay on language learning have found decidedly mixed 
results. Although many participants believe their contact with the host family to have been instrumental in their language growth (DuFon \& Churchill, 2006; Hernández, 2010; Di Silvio, Donovan, \& Malone, 2014), empirical studies have been unable to confirm these impressions. Magnan and Back (2007) were surprised by results that showed a

lack of relationship between various forms of language contact and language gain. It was expected that students who lived with native speakers, either in home stays or in apartments, would improve their speaking ability more than students who lived alone or with other Americans. This difference was not found. (54)

Allen (2010) investigates student contact with native speakers, examining linguistic engagement with the host family and other L2 contact in the local community. She reports a dearth of meaningful interactions with native speakers outside the home and finds that "[w]ith little exception, the only interlocutors with whom participants had repeated, sustained interactions in French were host family members" (16). Although the Allen study did not test language gain, it does include qualitative data detailing student perceptions of the effects of language contact on their linguistic gain. She proposes "a relational definition of SA as a learning context emerging from the dynamic interplay between the learner's intentions versus those in his or her community of practice" (20) as a way to combat the impression that SA will inevitably lead to L2 gain.

While the findings on the relationship between contact with native speakers and linguistic gain in the SA setting have been mixed, there are few published results on the value of speaking the target language with non-native speaking peers. Unfortunately, although the studies by Segalowitz and Freed (2004), Freed, Segalowitz, and Dewey (2004), and Hernández (2010) all employed the Language Contact Profile survey instrument (Freed, Dewey, Segalowitz \& Halter 2004) which includes a question that asks participants to differentiate the amount of time spent speaking the target language to native speakers as opposed to non-native speakers (question 6; 355), the reported findings of these studies do not detail how much time was spent in the target language with each group. Dewey (2007) found that vocabulary development increased with time spent speaking the target language with peers. The Freed, Segalowitz and Dewey study (2004) in which domestic immersion students showed more improvement than other groups hints that perhaps speaking L2 with other motivated non-native speakers can contribute to L2 gain.

Some studies that examine interaction with peers point strongly to the temptation to speak English, thus decreasing the contact time with the target language (DuFon \& Churchill, 2006; Magnan \& Back, 2007; Cadd, 2012; Du, 2013). A study by Magnan and Back (2007) reports a negative correlation between students speaking the target language together and their language gain. However, the qualitative data chosen to support this claim seems to confuse the issue of target language use with peers with that of too much English with peers. Magnan and Back (2007) conclude that

students who spent more time conversing with their American classmates in French improved significantly less on the OPI scale than students who spent less time conversing with American classmates in French.

This finding debunks the myth that speaking French with U.S. classmates helps students gain speaking proficiency while studying abroad. In fact, in the postprogram questionnaire, several students expressed regret about spending time with Americans: "I spent nearly all of 
my time with English speakers/American students ... I wish that I would have spoken less English and more French"; "I lived and socialized with Americans. I think this hurt my French.” (51-52).

Here it is clear that these student regrets center not on the challenge of the use of French with peers, but rather on the use of English with peers.

While all of these studies have been illuminating and informative, most have reported on small group samples and few have focused on the efficacy of using the TL with English-speaking peers. The present study is based on three years of language test, survey, and interview data involving a total of 123 students studying Spanish in three locations. The data reported in this article will answer the following questions:

1. What do students perceive as their linguistic gain after SA and what is their actual gain?

2. What do students perceive as most helpful to their language acquisition?

3. What do students perceive as most hindering their language acquisition?

\section{Methods}

The participants in this project were undergraduate students who studied abroad in one of three advanced Spanish language semester-long programs through a Midwest four-year liberal arts college from spring 2011 through spring 2014. During this time 93 students participated in programs in Spain, 60 in Peru, and 36 in Honduras. Each of the participants had completed at least one upper level course in Spanish prior to the semester abroad. In all three program locations students lived individually with local host families and enrolled in one or more classes with students from the home university, and most had at least one class with native students in the host university. Of the 189 students enrolled in the programs, $135(71 \%)$ consented to participate in the study and $123(65 \%)$ took part in one or more of the aspects of the study. The data collection tools included three components: a web-based survey (pre- and post-program), the Versant Spanish language test (preand post-program), and a post-program follow-up interview. The survey was a modified version of the Language Contact Profile ${ }^{1}$ (Freed, Dewey, Segalowitz, \& Halter, 2004).

\section{Survey}

The researchers administered the pre-program Survey A (15 items) and post-program Survey B (32 items ${ }^{2}$ ) through SurveyMonkey (http://www.surveymonkey.com; see Appendix). Survey A, sent by email during the month prior to departure, asked students to rate their pre-program language proficiency and to state their expectations for post-program language achievement. In addition, the

\footnotetext{
${ }^{1}$ To a large extent Survey B was modeled after the "Language Contact Profile" (LCP) of Freed, Dewey, Segalowitz, and Halter (2004). After an initial cycle with these survey items, response prompts about frequency of behaviors were revised. Whereas the 2004 LCP requires participants to first indicate the number of days per week and then the hours per day for each behavior, this proved to be cumbersome, and a number of students would discontinue the survey upon reaching these items. For this reason, the response prompt for these questions were changed to a single response of "hours per week."

${ }^{2}$ Survey B was modified to include two additional questions. The original survey contained 30.
} 
survey items prompted students to think about (1) how they might engage in various aspects of the host culture and (2) how they might allocate their time outside of class for language acquisition. Survey B, administered during the final weeks of the SA (1) posed detailed questions about how students spent their non-class time while in the host country; (2) asked participants to rate their postprogram language proficiency; and (3) surveyed students on the factors that most helped and hindered their language growth. One hundred twenty three students took part in the survey.

\section{Language test}

The Versant Spanish Test, designed by Pearson Education, is a computerized test delivered by phone or computer. The test has seven sections: Reading, Repeats, Opposites, Short Answer Questions, Sentence Builds, Story Retelling, and Open Questions. The test takes 13 to 17 minutes to complete. The testing system analyzes students' responses and posts scores online. Students are scored on sentence mastery, fluency, vocabulary, and pronunciation.

Because the Versant test can be administered via computer, it is available for students to take at their convenience. The lower cost of this test compared to the American Council on the Teaching of Foreign Languages' (ACTFL) Oral Proficiency Interview (OPI) made it more feasible for a study involving a large number of students. The ACTFL ratings reported in this study correspond to the score correlation information provided by Pearson Education (see references for more information).

Only students who completed Survey A were invited to take the Versant Spanish Test prior to departure. Only students who completed the pre-program Versant test (67) were allowed to take the post-program test, either in the final weeks of the program or in the two weeks immediately following. Fifty students took both the pre- and post-program language tests.

\section{Interview}

Seventy-six students $(56.3 \%)$ participated in the post-program interview consisting of 20-25 questions. A student researcher conducted the interview in person or by phone (according to interviewee preference) during the summers following the SA. Each interview was audio recorded and most lasted between 15 to 30 minutes with some up to 50 minutes. The student researcher then transcribed each interview and entered the data in QSR NVivo, a qualitative data analysis program. Each transcription was identified by program location, year, and an anonymous student identification number. Interview segments were highlighted, categorized, coded, and analyzed.

\section{Findings}

\section{Linguistic Gain}

\section{Students' self-rating}

In both Survey A and Survey B participants were asked to rate their level of proficiency based on the ACTFL scale. In Survey A they were asked not only to rate their current level of proficiency, but also to predict their anticipated post-program proficiency level. Prior to SA, of the 123 students who took the survey, 86 students $(69.9 \%)$ rated their proficiency in the Intermediate range, with half of that group reporting a proficiency level of Intermediate High. Another 24 students (19.5\%) rated themselves in the Advanced range. The remaining students (13, 10.6\%) chose the Novice level as indicator of proficiency. Nearly all of these students $(110 ; 89.5 \%)$ expected to attain an Advanced level by the end of the program: $19.5 \%$ at Advanced Low, 47.2\% at Advanced Mid, and 22.8\% 
expected Advanced High. Thus, students indicated hopes of proficiency improvement of at least two steps during SA (i.e., Intermediate Mid to Advanced Low or Intermediate High to Advanced Mid).

Survey B returned to these questions, asking participants to rate their post-SA proficiency level (see data in Table 1). Although only $8.9 \%$ of the participants initially believed that they would be at the Intermediate level by the end of their SA, when their program ended, $18.1 \%$ considered themselves to be at that level. Similarly, although nearly $90 \%$ of the participants expected to achieve the Advanced level, at the end of their program only $80 \%$ believed they were at that level $(37.1 \%$ at Advanced Low, 38.1\% at Advanced Mid, and 4.8\% at Advanced High). These data show that students initially expected to achieve a higher level than what they reported having attained by the end of the semester abroad. On a separate item in the survey, 65 students $(62 \%)$ reported that they were satisfied with their language progress.

Table 1. Student Perceptions of and Expectations for Language Achievement

\begin{tabular}{|l|l|l|l|l|l|l|}
\hline \multirow{2}{*}{} & \multicolumn{3}{|c|}{ intermediate } & \multicolumn{3}{c|}{ advanced } \\
\cline { 2 - 7 } & low & mid & high & low & mid & high \\
\hline Survey A: Pre-program self-rating ( $n=123)$ & $8.1 \%$ & $26.8 \%$ & $35.0 \%$ & $13.8 \%$ & $4.9 \%$ & $0.8 \%$ \\
\hline $\begin{array}{l}\text { Survey A: Pre-program expectations for } \\
\text { achievement ( } \mathrm{n}=123)\end{array}$ & $0.8 \%$ & $2.4 \%$ & $5.7 \%$ & $19.5 \%$ & $47.2 \%$ & $22.8 \%$ \\
\hline $\begin{array}{l}\text { Survey B: Post-program self-rating } \\
(\mathrm{n}=117)\end{array}$ & $5.7 \%$ & $0.0 \%$ & $12.4 \%$ & $37.1 \%$ & $38.1 \%$ & $4.8 \%$ \\
\hline
\end{tabular}

\section{Language test results}

Sixty-seven students took the Versant Spanish Test before their study abroad. Of those, only one student tested at the Advanced level, all the rest were at the Intermediate level, with $18(26.9 \%)$ at Intermediate High, $38(56.7 \%)$ at Intermediate Mid and $10(14.9 \%)$ at Intermediate Low. Fifty of these students also took the Versant Spanish Test after studying abroad. The data from this test indicated 50\% (25 students) rated at the Advanced level, with $22(44 \%)$ at Advanced Low and $3(6 \%)$ at Advanced Mid. The other half of the students were rated at the Intermediate level, with $1(2 \%)$ at Intermediate Low, $6(12 \%)$ at Intermediate Mid and 18 (36\%) at Intermediate High. On average, most students improved by at least one sub-level. Four students with the greatest gain rose by three sublevels, while a few showed no discernible improvement. Chart 1 compares the pre-program Versant scores with the students' pre-program perceptions of language level; Chart 2 compares the same data post-program. As is evident in these charts, students' self-ratings of proficiency both before and after SA tended to be higher than their rating from the Versant Spanish Test.

\section{Target language use}

According to the data from Survey A, prior to study abroad 93\% of participants believed they would communicate in Spanish at least $75 \%$ of the time they were abroad. And, indeed, when participants reported their hours per week spent talking in Spanish and English (question 6 of Survey B), the result was exactly that. The data from Survey B indicate an average of 25.7 hours per week (75\% of reported speaking time) spent speaking Spanish and 8.5 hours per week spent speaking English. However, although students had set and met their personal target for TL use, by the end of 
the program more than one-third $(38 \%)$ reported that they were unsatisfied with their linguistic progress.
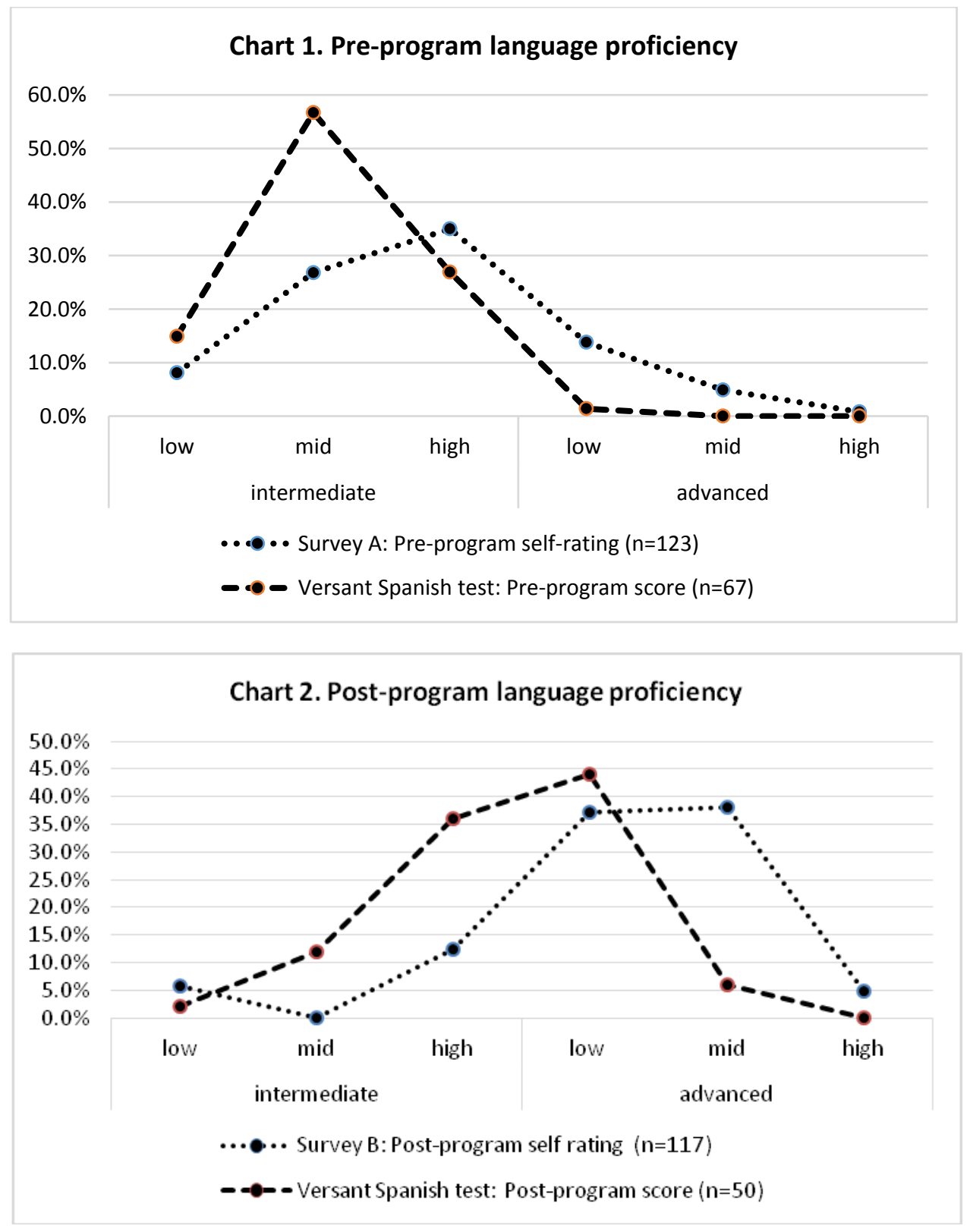

Aids to language acquisition

One of the questions on Survey B asked participants to rate various factors as to their helpfulness in improving language proficiency (see Chart 3). Clearly rising to the top of the list in the survey were "conversations with the host family" and "conversations with local students." 3 This was confirmed in

${ }^{3}$ Although it may seem surprising that "language/grammar class" ranks near the bottom for helpfulness, this likely was because very few of the students had a specific grammar class in their 
the interview data, however, the interviews revealed that participants also valued time spent in TL with non-native speakers as a significant aid to language progress.

Spanish with the host family

The interviews provided additional insights into what students found most helpful to their language learning, and these data mirror the survey data in that the most commonly mentioned aid to language growth was host family. A student from the Honduras semester valued the opportunity to live individually with the host family and "form a deeper connection" because "if students had to share a family...there'd be the temptation to have one dominant speaker... and the other one would do most of the listening. Not that you can't learn by listening, but you learn more by talking” (H1404). Many students mentioned the "hours and hours" that they spent talking with host family especially over meals. One student from the Peru program appreciated spending at least an hour of conversation at dinnertime with her "engaging family" of six and confessed that "sometimes I got lost when all of them were talking at once, but it was really good to be able to multi-task in my conversation skills, and focus on talking to more than one person at a time" (P11013). Several students found that watching television with the host family provided opportunities for conversation. One student in Spain noted "I was really intentional about forming a really good relationship with my Spanish mamá....We would sit in front of the television... [and] that became like a conversation catalyst for us. So that became an activity that I practiced, that I formed intentionally with a purpose of learning about the culture and learning about the language" (S11028). Another student from the same program mentioned "watching the news with my host family and talking with them about the news and how they reacted to the news...the general Spanish opinion" (S11025). A student from Honduras was clearly intentional about engaging with the host family, "Even if I wasn't talking to my family, I would listen to them, or just try to pull myself out of what's going on in the United States....So I tried to really just immerse myself as much as I could" (H1301).

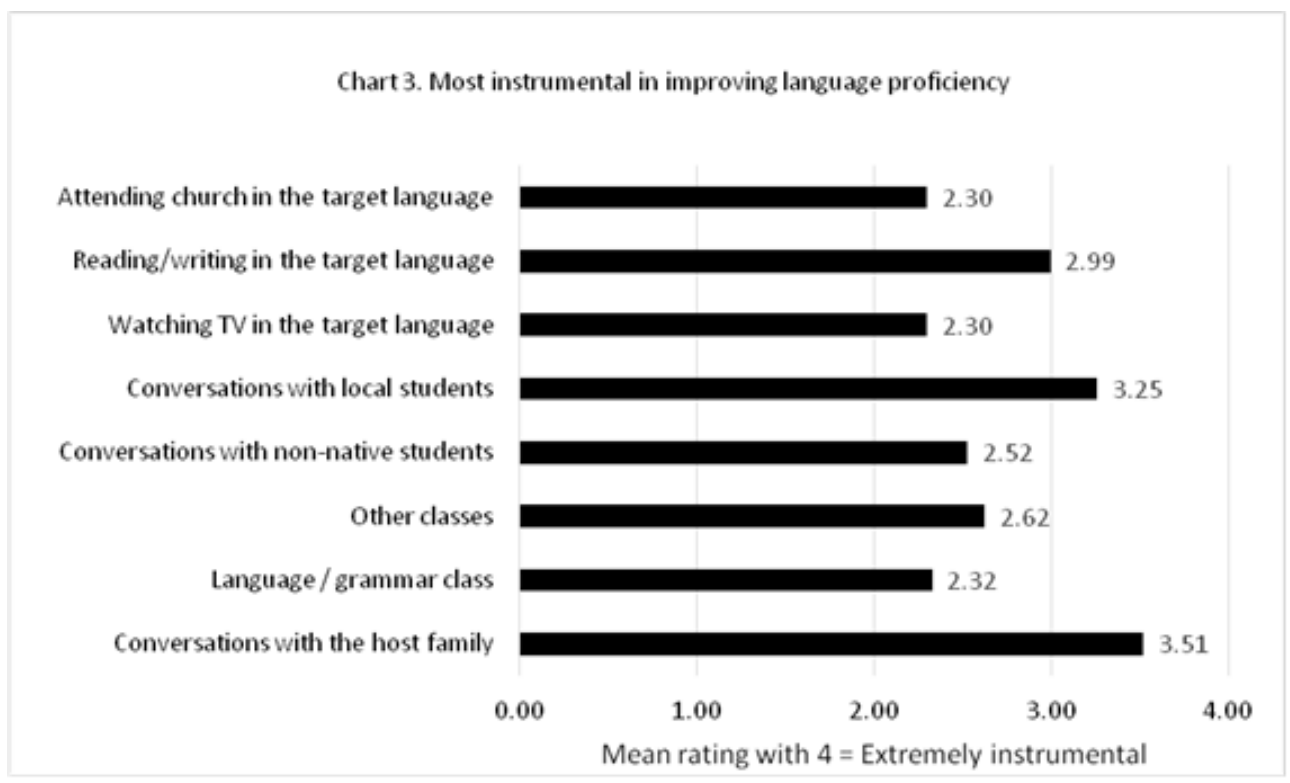

course schedule. 
As noted in Segalowitz and Freed (2004), host family interaction does not necessarily lead to increased language proficiency due to the "repetitive and often banal nature" of exchanges in the home (193). In line with this, one student complained about the host family saying, "We didn't really have deep conversation... we have absolutely nothing in common... so we just had a lot of daily chatter [and were unable to] speak about abstract concepts" (H1401). However, most students in the three programs gave overwhelmingly positive reports of interactions with their host families. Indeed, one student explained, “We talked a lot about... deeper and broader subjects. We talked about women's rights and stuff like that, and just having those more abstract conversations I think really deepened my understanding of the language and the vocabulary....[This also] gave me a glimpse into the Spanish culture" (S12027).

\section{Spanish with native-speaking peers}

Closely following the host family in ranking as aid to language learning was the importance of forming relationships with native Spanish-speakers, and especially peers,

because there's just something about hanging out with somebody your own age....We all think more alike, even though we're from different parts of the world...it helped me learn how to express myself as a young adult in Spanish. (P11006)

Learning slang appealed to some students since "when you talk to people your age...you can learn how people talk outside of formal settings" (P11033). Another stated benefit of spending time with native speakers was that students

were not tempted to slip into English because [our Peruvian friends] would not understand and it would be rude. This made Spanish a necessary part of enjoying time with others. It forced me out of my comfort zone and attached good memories with Spanish that made me love the language even more. (P11016)

A number of students acknowledged their own responsibility in improving their language skill and took advantage of every opportunity to "consciously seek out conversations with native speakers" (H1401) and, conversely, to avoid speaking English. In fact, this research shows that, of the students whose Versant test data could be linked to individual survey responses $(n=28)$, the most language gain, as indicated by the score increase, was found among the students who reported spending less time speaking English (see Table 2). Although individual student results varied, by aggregating the students a clear trend emerges. The students with the greatest increase in language test scores reported an average of only 5.78 hours of English per week, whereas the students in the lowest third reported an average of 13 hours of English per week, more than double that of the high achieving group.

Table 2. Comparison of average increase in language score with time spent speaking English

\begin{tabular}{|l|l|l|}
\hline & $\begin{array}{l}\text { average point increase in language test } \\
\text { score }\end{array}$ & $\begin{array}{l}\text { average hours per week spent speaking } \\
\text { English }\end{array}$ \\
\hline $\begin{array}{l}\text { top third of students ranked by } \\
\text { language gain }\end{array}$ & 18.89 & 5.78 \\
\hline $\begin{array}{l}\text { middle third of students ranked by } \\
\text { language gain }\end{array}$ & 10.31 & 7.90 \\
\hline $\begin{array}{l}\text { bottom third of students ranked by } \\
\text { language gain }\end{array}$ & 3.67 & 13.00 \\
\hline
\end{tabular}




\section{Spanish with non-native speaking peers}

Although Magnan and Back (2007) reported a "significant negative relationship between speaking French with other Americans and improvement in speaking proficiency on the OPI" (56), a number of students in the current study believed that speaking Spanish even with non-native speakers (NNS) was beneficial to their language growth.

It helps a lot that we were expected to speak Spanish with each other and so we learned from Spanish speakers, but we also learned from...the phrases and words that our fellow students would pick up and just from talking with each other. So that was really helpful, (H1402)

said one student in Honduras.

The degree to which these language behaviors are not automatic but rather the result of intentional decisions is evident in this student's statement:

Really trying to foster an environment of Spanish speaking among the [home university] group was really important. A lot of the other American students would never speak in Spanish with each other, so our group, while it wasn't perfect, we definitely gave it a pretty good effort to try to speak in Spanish, at least during the day. My policy was usually Spanish from 9AM to 9PM, and then after that I could talk in English with my friends. (S12014)

Many other students echo this need for explicit attention to speaking in the TL:

Our group was pretty intentional about sticking to our Spanish. So even if we took trips just together as a class, continuing to speak the language and just force ourselves to be using the language all the time and commit to a total immersion for the semester was vital, I think, for all of us. (H1304)

Speaking Spanish with the English-speaking students, like the [home university] students [was one of the factors most instrumental to my language growth]. That was a big part of it because it was really tempting just to speak English. It's easier, [and] your humor is better in English. But you really had to be intentional... about speaking in Spanish, and it really helped you get better 'cause that was who you talked to most. (P11017)

This sentiment was not limited to any one program location or year, but was expressed by several students across all programs:

I tried my hardest to always talk in Spanish even with [home university] people...like walking to the university with somebody and just talking about what I ate for lunch or what I did in class earlier. Things like that really helped me, I thought, at least with my speaking skills....I'm really glad that I did that 'cause now I actually have the confidence to speak in Spanish, whereas before I didn't really want to because I was too scared to. (S12007)

[Speaking in Spanish with native English speakers] was very helpful because they were struggling with the same things I was struggling with... [we] could kind of lean off of each other and build off of each other's knowledge. (H1403)

I didn't think [speaking Spanish with native English speakers] would be that helpful, but it was really, really helpful actually because if someone's learning right along with you, you can 
be like, wait, what did you say? And can you slow down? Say it again. What does that mean? (P1306)

Wilkinson (1998) and Allen (2010) point out various negative effects of American students congregating together while abroad, particularly to their language learning. However, one student in this study discovered that speaking in Spanish as a group actually smoothed their entry into the local community. Speaking Spanish with native English speakers "was really helpful, and I think made a huge difference... in helping us to meet new friends at the university and around the city. Peruvians were really impressed and less intimidated by us when we spoke Spanish together.” (P1308)

\section{Additional aids to language gain}

Some participants highlighted the benefit of error correction that occurred within a safe or comfortable context. A student in Peru commented, "I told [my host family] I wanted to be corrected and they definitely helped me on that. So they were very willing to teach me and also it was never uncomfortable to say something wrong" (P1301). Another student in the same program remarked that the family

found a really good balance of being able to help me with the things that I was struggling with on a regular basis but not calling me out on every little thing to make me feel like I couldn't speak Spanish... My whole family sometimes would be able to say, 'This thing grammatically you need to work on,' and so in my family was the only place that I got feedback on grammar. (P1302)

One student in Honduras stated that

it was very, very important for me [to have conversations] with people who wanted me to learn. It wasn't with someone who was just going to give up....If I had a question, they didn't mind me stopping them, and they would be like, 'Oh, have you heard this before? Let me tell you what this word is.' (H1305)

\section{Another student said,}

I'm sure I didn't speak correctly all the time, but I never heard anything about that from [my host family]. They never laughed or mocked me. So I think just having that safe environment to speak and get practice... was really helpful. (S11004)

In several of the programs students are paired with a "tandem partner" (native speaker) for weekly conversational practice. One student found that to be a conducive environment for learning "because hanging out with people is cool but sitting down and conversing really shows where you are with your Spanish and helps you improve, especially when someone's there to correct you and tell you things that you do wrong" (S12021). Another appreciated the tolerance with which the host family listened:

[My host family was] so patient with me when I was learning the language. They waited for me when I talked slowly, gently corrected my mistakes, and filled in when I couldn't remember the right words. The way they included me in all kinds of things they did was also very instrumental in my language learning. (P11016) 


\section{Hindrances to language acquisition}

Survey B also asked students to report on factors that hindered language proficiency during the semester abroad (see Chart 4). The single strongest factor was the "personal choice to speak English with other students in the group" (mean of 2.89) followed fairly closely by "using technology in English" and "lack of support from peers" (2.30 and 2.22, respectively).

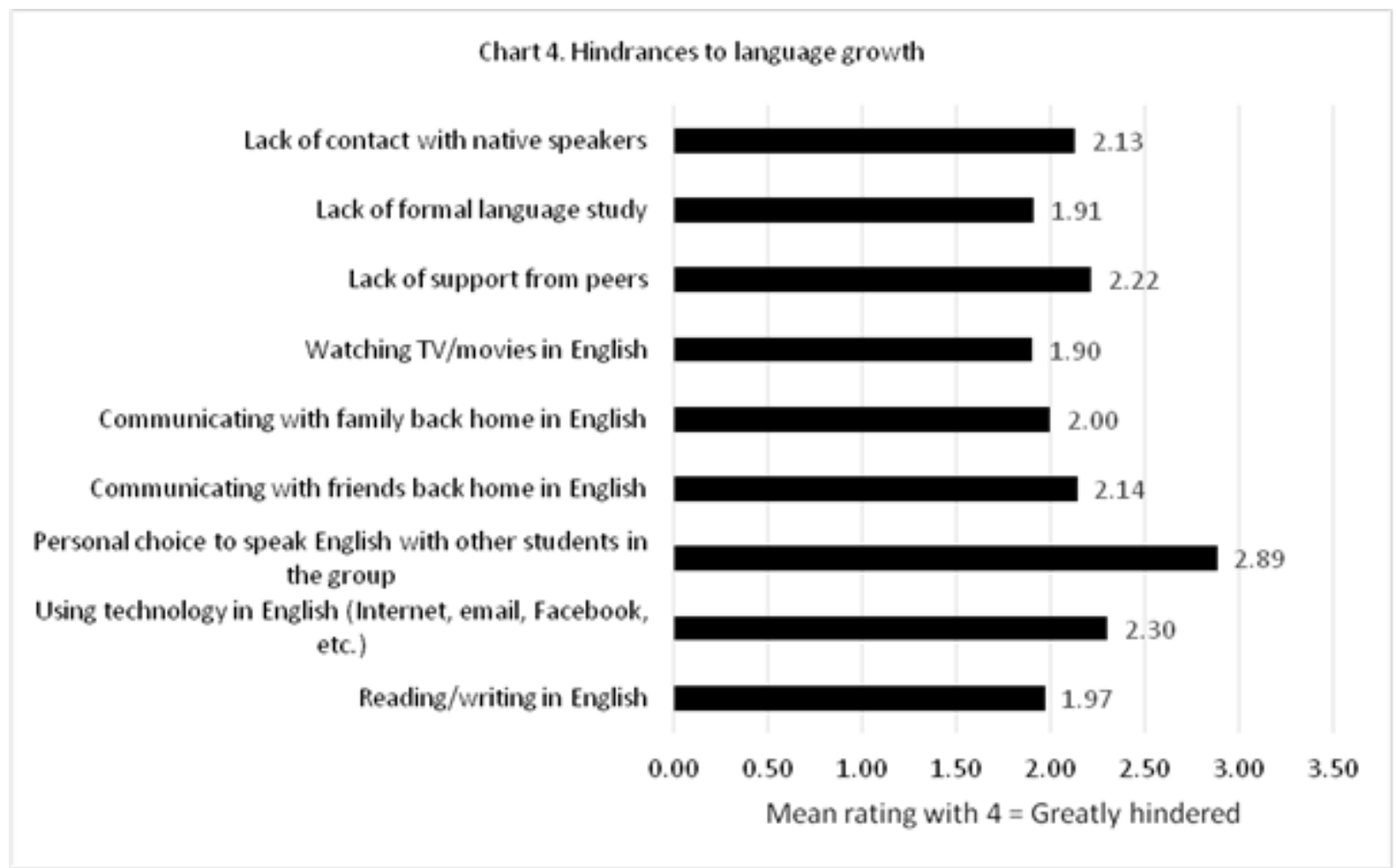

\section{Personal choice}

The interview data echo the findings in the survey. In the interviews a majority of students mention their use of English as the most significant factor that hindered their language growth. Interestingly, rather than expressing this as a "personal choice" (as in the survey prompt), students used phrases such as "fell into English," "revert back to English," "broke down and spoke English," and "lapsed into English."

Some of the reasons given for speaking English together were being "tired," "lazy," "homesick," "it was the easy way out," or "[I] couldn't handle more Spanish." The perception of the difficulty of persevering in the use of the L2 is apparent in the following comments: "I think towards the end, people were just kind of giving up, they saw the end in sight and they started speaking a lot of English" (H1302); "when you're going through a lot emotionally and spiritually....those were the times when we would let ourselves speak more in English" (H1304); and "instead of struggling through the Spanish with each other, especially when we were working on homework and such, we would just default to trying to explain everything in English" (P11015). And one student simply admits, "I guess...I could have chosen to speak in Spanish a hundred percent of the time with people from [home university] if I really wanted to" (H12036). 
Students tended to explain their failure to persist in Spanish by appealing to competing priorities, particularly the need to form deep relationships with their peers. Typical of these justifications was the explanation given by a Honduras student,

It becomes very difficult to make deep friendships in a language that you're not comfortable with....I think that because our community was just the 15 of us, and I wouldn't trade that. I think those girls made the trip and so I don't mind that my Spanish ability was hindered by being part of that community. That's a choice that I made that they were a priority over my Spanish ability. (H1401)

Another student discusses the importance of relationships, this time with friends and family at home, as competing for her linguistic allegiance:

I also think the amount of communication I had with home probably hindered....Most days I would email my parents just really quick, not like a huge email to them but say something to them, and email my boyfriend or just other friends at home. So definitely that email communication, Skype communication probably didn't help. But that was something I was willing to sacrifice. I didn't want to lose contact with the people at home that I love, so I think that was something I was willing to sacrifice. (S11004)

An environment in which the choice to speak English came up repeatedly was during group travel away from the program location. Students recognized the English-speaking bubble of touring cultural sites together and also blamed the fact that speaking English was "the most efficient way to get things done" (S11028) when they traveled independently. In the same vein, another student admitted,

When we went on spring break, we spoke in English. Like we kind of made that decision because we were traveling by ourselves and, you know, we didn't want there to be any miscommunication, and so part of it-I think we sort of made the excuse that it was a safety precaution, which I feel like kind of works....I don't necessarily regret that decision, that we made it kind of like an English week. (H1404)

Thus, when students were unsuccessful in maintaining their initial resolve to speak only the L2 during the SA, they recognized this as a conscious choice and found a way to justify their decision.

\section{Technology}

The second most common response to hindrances to language growth had to do with technology. Students from all three programs mentioned "open access to the internet" and frequent use of social media to connect with family and friends back home. One student said,

I couldn't ever completely switch over to Spanish because I was sending emails to my parents or writing on a blog or Skyping with somebody from home and using English for that, so I feel like English was always being used. (P1202)

Besides the obsession with social media, students admit to indulging in American Netflix binges and acknowledge that

by staying on Facebook and by Skyping a frequent amount, or by trying to keep up with the television shows at home, I think those were probably things that perhaps hindered my language development. (S12012) 
A more thoughtful student wished that access to social media could be blocked because "if you engage too much in that, it can really hurt your Spanish" (S1306).

Not only language growth but also social interaction suffers because of the pervasiveness of social media. One student admitted to using technology as an escape from both the language and the culture of the host country:

One of the factors that hindered my language growth was I just had open access to the internet and so sometimes it was just like, I go home and go sit in my room and close the door and, it's like, I'm going to have English time now and go on Facebook and talk with friends from the States and look at various websites in English and stuff and just forget that I'm in Spain for a while. (S12011)

\section{Peers}

A third significant hindrance mentioned by students in the survey and the interviews is a lack of support from peers. Although students feel more secure participating in a program with a peer group in which they have pre-existing relationships (Wilkinson, 1998), these very relationships may become hindrances. Typical were comments like,

Having close friends on the trip...might have inhibited me in a way because I'm so used to speaking to them in English that it was hard to speak in Spanish with them when I'm so used to them in a different context. (S11032)

This student's statement affirms the contradictory influence of peer relationships in the SA context. On the one hand, as we have seen earlier, speaking L2 with peers can be beneficial to language growth; but at the same time peer pressure can inhibit a student's willingness to engage in the "risk" of speaking the target language.

This finding supports the results of Allen (2010) in her study of 18 students in France. Her data indicated that the majority of the students in the program viewed their American peers as a "motivational constraint" (15) for using the target language. Allen claims:

More than half of participants (eleven) felt that their American peers and, more specifically, the influence of the group more so than specific individuals in it, were disadvantageous for efforts to communicate in [the target language]. (14)

Similarly, in our interviews a student from the program in Spain noticed that "if one student was speaking English... it was just easier to continue that and a lot harder if you did want to speak Spanish" (S12003). A student from Peru reported that "it was so hard ... [the other students in the group] would be speaking in English and you'd try to speak Spanish back... and then they don't listen to you, so then you have to say it in English" (P1204). One participant from the same group complained about specific peers "who would refuse to speak Spanish... [so it wasn't] an environment where you were comfortable speaking Spanish all the time. It was kind of like, 'Oh, you're speaking Spanish right now? Come on!'” (P1207). Allen (2010) also mentions the consequence of negative peer pressure as "linguistic demotivation and anxiety that if a participant persevered in speaking [the target language], it would result in rejection by peers" (14).

Students abroad interact not only with peers from their home institution, but also with peers from 
other American universities and English-speaking international students. These peers influence students' linguistic behavior as well. One interviewee details the challenge saying:

We all walked in with the mindset that we are going to be speaking Spanish together 24/7, and that was kind of the goal. But then, once we met other American students, they didn't come in with that mindset, and I don't think they were encouraged by their university professors to do that. So they were constantly speaking in English. So, you know, it would be rude to not respond in English to them, so we spoke a lot of English with other American students. Also, I met students from other countries as well. [One student from Finland] was at a lower Spanish speaking level than I was but he spoke English fluently, so we spoke in English together 24/7 because it would have been too difficult to try to speak in Spanish to him. (S12027)

This participant goes on to say that she appreciates the opportunity to interact with people from all over the world, but recognizes the negative impact of English as a dominant world language on her Spanish language growth.

Some students acknowledged that, in the end, language learning was their responsibility. One student put it best, "I wish that I would've pushed people to speak Spanish more. If people spoke to me in English, it's not like I was going to respond in Spanish. And maybe I should have." (S1403).

\section{Summary of findings}

Using language testing, survey and interview data, this study explored student perceptions of (1) initial proficiency level and proficiency gain; (2) time spent in the TL; and (3) helps and hindrances to language gain during SA.

In general, students' self-rating of proficiency tended to be higher than the rating indicated by the language test results. While this might be explained by over confidence, it may also reflect a lack of understanding of the ACTFL levels. Although the survey question gave a brief description of each level, participants might not have grasped the distinctions between the proficiency levels. Despite the fact that the students' perceived rating was inflated according to the actual Versant scores, $92 \%$ of the participants did show improvement in language scores from pretest to posttest.

According to students' self-reported time spent in L1 and L2, students accurately predicted the amount of time that they would spend speaking the native and the target language while abroad. This finding juxtaposes interestingly with the data from the survey showing that the students themselves recognize the greatest hindrance to L2 improvement was the personal choice to spend time speaking English while abroad.

Not surprisingly, conversations with host family and conversations with local students both ranked first and second for greatest aids to language growth. The program structure which included a home stay and emphasized connections to the local university allowed students the opportunity to build relationships with native speakers. Although the data show that students valued this aspect of their SA, a number of students noted the intensity of personal effort required for this level of engagement.

Interestingly, both of the top two hindrances selected by the students on the survey, "Personal choice to speak English" and "Using technology in English," also fall within the realm of personal 
volition. The responsibility for L2 engagement lies squarely with the student. Unlike the top two, the third ranked hindrance according to the survey, "Lack of support from peers," is not under the students' control.

\section{Conclusion}

The results of the present study suggest that one of the primary underlying factors behind successful language study in SA contexts is the intentionality of the participants' engagement with the various elements of the SA program. Students acknowledged that successful interaction with native speakers required sustained personal effort. They also remarked about the value of intentional L2 communication with NNS peers.

Program design and content, while important, are most successful when individual student volition is activated. Participants in this study repeatedly pointed to the personal effort required for building relationships with the host family and other native speakers in the local setting. Students should be encouraged to take the initiative in relationships and should be warned not to expect them to spring up effortlessly. The immersion context is essential, but its effectiveness depends on the student fully exploiting the opportunities for engagement with the host family, with the local peers, and also with the NNS peers in the SA program.

In order to facilitate L2 contact, many SA programs feature home-stays and organize native conversation partners for students ${ }^{4}$. These experiences provide participants with connections to local native speakers and abundant opportunities for oral practice. However, unless it is carefully structured, this oral practice might never advance beyond the Intermediate level due to the routine nature of many of these types of conversations. Once again, students must be intentional about engaging in conversations that require more complex structures and sophisticated vocabulary if they wish to make significant L2 gain.

Realistically, even with the above opportunities, students will be in contact with NNS peers during their SA. As has been shown, this contact can be either positive or negative. When students fail to maintain the L2 with NNS peers, the personal effort that they would invest in conversations with native speakers is the critical component that seems to be lacking. Wilkinson (1998) and Allen (2010) noted the negative aspects of American peer groups. However, while some students in our study found the peer group dynamic to be demotivating, others rose above this barrier and intentionally spent significant time speaking in Spanish to those in their home university peer group. As reported in the interviews, these students believed that the time spent in the TL with their American peers strengthened their L2 skills.

Because student intentionality in L2 learning is critical, it is helpful for SA directors to inform students what current research says about peer influence on language learning during SA. Students need strategies for turning potential negatives into positive learning opportunities. Much of this groundwork must be laid before the students leave their home country so that relationships with peers are built around an L2 foundation. Study abroad program directors and world language (WL)

${ }^{4}$ Another program model provides each student in the program with a local tutor for their academic work. In theory, the exchanges between the student and the tutor are more likely to involve Advanced and even Superior speaking levels. 
professionals must also be intentional about providing training and tools for students prior to and during SA. Students must be made aware of common pitfalls facing SA students and urged to take ownership of the L2 learning process by proactively seeking opportunities to advance their fluency in the L2. To that end, professors and program directors can provide vital resources such as conversation prompts; formal assignments that give students an "excuse" for initiating L2 exchanges; assignments requiring oral output; and lists of conversation openers, closers, and connective elements.

Students reported one of the reasons for speaking English with peers was the difficulty of getting to know one another and to express their personalities in the TL. Rather than seeing this as a negative, students should be encouraged to embrace the opportunity to develop other aspects of their character that emerge within the SA context. Although issues of identity are beyond the scope of this study, SA program directors should alert students to this challenge and invite them to strategize ways to combat this issue. Student awareness of the difficulties they are likely to face will not make them disappear; however, awareness can help equip students to manage the obstacles as they arise.

The findings of this study suggest that more research is necessary in several areas. As noted by Dewey, et al. (2014), the accuracy of student self-reporting of time spent in L1 and L2 should be assessed objectively since students may tend to over- or underestimate time spent in either language. Certainly, investigating the quality of the conversational exchanges, Intermediate vs. Advanced/Superior level speech, and comparing that with student L2 gain will provide a better picture of what truly happens in an SA context. Going forward, researchers will need to investigate whether raising awareness of challenges and providing appropriate tools to overcome them, as mentioned earlier, positively correlates to increased L2 gain. As SA program directors and WL professionals develop a deeper understanding of the variables that impact the L2 learning process, they can better structure programs to maximize the SA opportunity.

\section{Acknowledgements}

We wish to express appreciation to our two McGregor Summer Research Fellows, Katie Van Zanen and Brianne Dekker, for their tireless work and their creative energy.

We gratefully acknowledge grants from the Calvin Center for Social Research, the Kuyers International Program Fund, and the Calvin Teaching and Learning Network.

\section{References}

Allen, H. (2010). Interactive contact as linguistic affordance during short-term study abroad: Myth or reality? Frontiers: The Interdisciplinary Journal of Study Abroad, 19, 1-26.

Brecht, R.D., Davidson, D. \& Ginsberg, R. (1995). Predictors of foreign language gain during study abroad. In B. Freed, (Ed.) Second language acquisition in a study abroad context (pp. 37-66). Philadelphia: John Benjamins.

Cadd, M. (2012). Encouraging students to engage with native speakers during study abroad. Foreign Language Annals, 45(10), 229-245.

Dewey, D. (2007). Japanese vocabulary acquisition by learners in three contexts. Frontiers: The Interdisciplinary Journal of Study Abroad, 15, 127-148.

Dewey, D., Bown, J., Baker, W., Martinsen, R. A., Gold, C., \& Eggett, D. (2014). Language use in six study abroad programs: An exploratory analysis of possible predictors. Language Learning, 64(1), 36-71. 
Di Silvio, F., Donovan, A. \& Malone, M. E. (2014). The effect of study abroad homestay placements: participant perspectives and oral proficiency gains. Foreign Language Annals, 47(1), 168-188.

Dörnyei, Z. (1990). Conceptualizing motivation in foreign-language learning. Language Learning, 40, 45-78.

Du, H. (2013). The development of Chinese fluency during study abroad in China. The Modern Language Journal, 97(1), 131-143.

DuFon, M. A., \& Churchill, E. (2006). Evolving threads in study abroad research. In M. A. DuFon \& E. Churchill (Eds.), Language learners in study abroad contexts (pp. 1-27). Clevedon, England: Multilingual Matters.

Freed, B. F. (1995). What makes us think students who study abroad become fluent? In B. F. Freed (Ed.), Second language acquisition in a study abroad context (pp. 123-48). Philadelphia: John Benjamins.

Freed, B. F., Dewey, D., Segalowitz, N., \& Halter, F. (2004). The language contact profile. Studies in Second Language Acquisition, 26(2), 349-56.

Freed, B. F., Segalowitz, N., \& Dewey, D. (2004). Context of learning and second language fluency in French: Comparing regular classroom, study abroad, and intensive domestic immersion programs. Studies in Second Language Acquisition, 26(2), 275-301.

Hernández, T. A. (2010). The relationship among motivation, interaction, and the development of second language oral proficiency in a study-abroad context. The Modern Language Journal, 94(4), 600-617.

Isabelli-Garcia, C. (2006). Study abroad social networks, motivation and attitudes: Implications for second language acquisition. In M. A. DuFon \& E. Churchill (Eds.), Language learners in study abroad contexts (pp. 231-258). Clevedon, England: Multilingual Matters.

Kinginger, C. (2009). Language learning and study abroad: a critical reading of research. Basingstoke, United Kingdom: Palgrave Macmillan.

Kinginger, C. (2010). American students abroad: Negotiation of difference? Language Teaching 43(2), 216-27. Cambridge Journals Online. 9 Feb. 2009. Web. 30 May 2012.

Krashen, S. (1981). Second language acquisition and second language learning. New York: Pergamon Press.

Lafford, B, \& Collentine, J. (2006). The effects of study abroad and classroom contexts on the acquisition of Spanish as a second language: From research to application. In R Salaberry \& B. Lafford (Eds.), The art of teaching Spanish: Second language acquisition from research to praxis (pp.103125). Washington, D.C.: Georgetown University Press.

Magnan, S. S. \& Back, M. (2007) Social interaction and linguistic gain during study abroad. Foreign Language Annals, 40(1), 43-61.

Martinsen, R., Baker, W., Bown, J., \& Johnson, C. (2011). The benefits of living in foreign language housing: The effect of language use and second-language type on oral proficiency gains. Modern Language Journal, 95, 275-290.

Martinsen, R. A., Baker, W., Dewey, D. P., Bown, J., \& Johnson, C. (2010). Exploring diverse settings for language acquisition and use: Comparing study abroad, service learning abroad, and foreign language housing. Applied Language Learning, 20, 45-69.

Mendelson, V. (2004). "Hindsight is 20/20:" Student perceptions of language learning and the study abroad experience. Frontiers: The Interdisciplinary Journal of Study Abroad, 10, 43-63.

NVivo qualitative data analysis software; QSR International Pty Ltd., Version 8, 2008, Version 9, 2010.

Segalowitz, N. \& Freed, B. F. (2004). Context, contact, and cognition in oral fluency acquisition: Learning Spanish in at home and study abroad contexts. Studies in Second Language Acquisition, 26(2), 173-199.

Versant Spanish Test Validation, http://www.versanttest.com/technology/VersantSpanishTestValidation.pdf accessed July 9, 
2014.

Versant Spanish Test and ACTFL Oral Proficiency Interviews Correlation, http://www.pearsonhighered.com/versant/assets/Fact $\% 20$ Sheet Versant $\% 20$ Spanish compari son to ACTFL Level.pdf accessed July 9, 2014.

Wilkinson, S. 1998. Study abroad from the participant's perspective: A challenge to common beliefs. Foreign Language Annals 31(1), 23-29. 


\section{Appendix}

Survey B

Thank you for taking the time to complete this survey regarding certain aspects of the Spanish semester abroad experience. Your feedback will help us improve the program. This survey should take only 10-15 minutes of your time. Your answers will be completely anonymous.

1. Before your semester abroad, how would you rate your oral language proficiency? NOTE: INTERMEDIATE level speaks in complete sentences about everyday situation and can use tenses but not always accurately. ADVANCED level can speak in paragraphs about abstract topics and can use all tenses accurately (i.e. past).
Intermediate Low
Advanced Low
Intermediate Mid
Advanced Mid
Intermediate High
Advanced High

2. Your expectations BEFORE the semester abroad: What percentage of your time OUTSIDE of class did you think you would speak Spanish?
$90-100 \%$
$\square 75-89 \%$
$50-74 \%$
$25-49 \%$
less than $25 \%$

3. During your semester abroad, outside of class, with whom did you try to speak Spanish? Hours per week
- my instructors
- friends/classmates who are native Spanish speakers
- friends/classmates (non-native speakers)
- strangers
- host family
- service personnel (waiters, janitors, etc.)
- $\quad$ other (please specify):

4. How often did you use Spanish outside the classroom for each of the following purposes? Hours per week

- to clarify classroom related work

- to obtain directions or information

- for superficial or brief exchanges (e.g. greetings, "Pass the salt," "I'm leaving," ordering in a restaurant) with host family or acquaintances

- $\quad$ extended conversations

5. How often did you... daily weekly seldom never

- $\quad$ try intentionally to use things you were taught in the classroom with native speakers outside the classroom?

- $\quad$ take things you learned outside the classroom back to class for question or discussion?

6. How much time did you spend doing the following each week? 
Hours per week

- $\quad$ speaking Spanish to native speakers of Spanish

- $\quad$ speaking English to native speakers of Spanish

- $\quad$ speaking Spanish to non-native speakers of Spanish (e.g., Americans or other English speakers

- $\quad$ speaking English to non-native speakers of Spanish (e.g., Americans or other English speakers)

7. During your semester abroad, in which of the following did you participate?

Hours per week

- $\quad$ social activities with native Spanish-speakers

- $\quad$ social activities with non-native Spanish-speakers (e.g., Americans or other English speakers)

- $\quad$ sports and fitness activities with native Spanish-speakers

- conversation partners

- $\quad$ tutoring sessions

- $\quad$ volunteer work or service learning

- $\quad$ Bible study with native Spanish-speakers

- $\quad$ Bible study with [university] students in English

- Bible study with [university] students in Spanish

- $\quad$ church services

- $\quad$ individual devotions in English

- $\quad$ individual devotions in Spanish

- $\quad$ other (please specify)

8. How much time did you spend WRITING in Spanish OUTSIDE OF CLASS?

Hours per week

- $\quad$ overall, in writing in Spanish OUTSIDE OF CLASS

- $\quad$ writing homework assignments in Spanish OUTSIDE OF CLASS

- writing personal communications in Spanish (including Internet and texting OUTSIDE OF CLASS)

9. How much time did you spend READING in Spanish OUTSIDE OF CLASS?

Hours per week

- $\quad$ overall, in reading in Spanish OUTSIDE OF CLASS

- $\quad$ reading Spanish newspapers or magazines OUTSIDE OF CLASS

- $\quad$ reading books in Spanish OUTSIDE OF CLASS

- $\quad$ reading email or Internet web pages in Spanish OUTSIDE OF CLASS

10. How much time did you spend LISTENING to Spanish OUTSIDE OF CLASS?

Hours per week 
- $\quad$ overall, in listening to Spanish OUTSIDE OF CLASS

- $\quad$ listening to Spanish television or radio OUTSIDE OF CLASS

- $\quad$ listening to Spanish movies or videos OUTSIDE OF CLASS

- $\quad$ listening to Spanish songs OUTSIDE OF CLASS

- $\quad$ listening to other peoples' conversations in Spanish OUTSIDE OF CLASS

11. How often did you do the following activities IN ENGLISH during the semester?

Hours per week

- $\quad$ reading newspapers, magazines, or books IN ENGLISH

- watching movies, television or videos IN ENGLISH

- $\quad$ using social media IN ENGLISH (e.g., Facebook, email, Skype)

- $\quad$ speaking with your peers IN ENGLISH

12. During the semester, how often did you engage in discussions IN ENGLISH about abstract topics such as...?

- political/economic questions

daily often seldom never

- religious/spiritual questions

- controversial issues

- philosophical questions

- questions of identity

- other (please specify)

13. Why or why not?

14. During the semester, how often did you engage in discussions IN SPANISH about abstract topics such as...?

- political/economic questions

daily often seldom never

- religious/spiritual questions

- controversial issues

- philosophical questions

- questions of identity

- other (please specify)

15. Why or why not?

16. Did you take the OPI (Oral Proficiency Interview) during the semester?

Yes

$\square$ No

17. If you took the OPI, did you achiever a level of Advanced Low or above?
Yes
$\square$ No
I don't know yet 
18. After the program, how would you rate your oral language proficiency? NOTE: Intermediate level speaks in complete sentences about everyday situation and can use tenses but not always accurately. Advanced level can speak in paragraphs about abstract topics and can use all tenses accurately (i.e. past).

$\square$ Intermediate Low

Intermediate Mid

Intermediate High
Advanced Low

Advanced Mid

Advanced High

19. Did you make as much progress in your oral proficiency as you had hoped?

$\square$ Yes

$\square$ No

Comment:

20. Which of the following were most instrumental in improving your language proficiency?

- conversations with the

$\begin{array}{llll}\text { Extremely } & \text { Very } & \text { Somewhat } & \text { Not } \\ \text { instrumental } & \text { instrumental } & \text { instrumental } & \text { instrumental }\end{array}$

host family

- language/grammar

class

- $\quad$ other classes

- conversations with

non-native students

- conversations with

local students

- watching TV in the

target language

- reading/writing in the

target language

- $\quad$ attending church in the

target language

- $\quad$ Please elaborate:

21. How much did the following factors hinder your ability to improve your language proficiency?

Greatly

hindered
Did not

hinder

- $\quad$ reading/writing in English

- $\quad$ using technology in English (Internet, email, Facebook, etc.)

- personal choice to speak English with other students in the group

- $\quad$ communicating with friends back home in English

- communicating with family back home in English 
- $\quad$ watching TV/movies in English

- lack of support from peers

- $\quad$ lack of formal language study

- lack of contact with native speakers

- $\quad$ Please elaborate:

[Questions 22-29 asked students about religious/spiritual engagement during study abroad.]

30. In what year did you participate in the Spanish semester abroad program?
$\square$ Sophomore
$\square$ Junior
$\square$ Senior

31. What is your gender?

Male

Female

32. How would you characterize yourself?

- introverted

- somewhat reserved

- neither reserved nor outgoing

- outgoing

- quite extroverted

Thank you for participating in this survey! We value your input. 